\title{
Partial Discharge Analysis on Isolator of Transformer
}

\author{
Bachtiar Antonov, Thomas Thomas \\ Institut Teknologi Padang, Electrical Engineering Department, Padang, West Sumatra, Indonesia
}

\begin{abstract}
Transformer has an important role in the world of electricity, especially high voltage. The selection of transformer isolation and routine maintenance should be in the same direction to maintain the reliability of transformer performance and work safety. Partial discharge is caused by many factors, both from the transformer itself, breakdown voltage and the use of an old transformer. The external factor is the temperature around the transformer which results in a decrease in the reliability of the insulator. Both must be based on a standard. As technology advances, in the field of electrical, electronics, computerization has a standard called IEEE Std C57.104 тм -2008 which is a revision of IEEE Std C57.104-1991. It is designed for science and technology guidance concerning all provisions concerning the security of the worker itself. Which later, by applying the standard is expected transformer service users can suppress loss of production and work accidents. Indication of occurrence of Partial discharge (PD) occurs in transformer at MCC CLO2 (transformer 1) where TDCG 25975 ppm and transformer EN-2M also occur Partial Discharge (transformer 2) with TDCG 5920.6 ppm, while at transformer VE-12 (transformer 3) is still in normal condition where the TDCG value is only $630 \mathrm{ppm}$. If the Partial Discharge is fatal and damaging the transformer, replacement of the transformer should be done immediately. But the condition of the field not be done directly because of many stages to be done, which directly affect the production process and costs.
\end{abstract}

\section{Introduction}

The use of high voltage is one effort to reduce the loss of energy in the system of transmission and distribution of electrical power from a power generator which is located far from each other. Because by raising the voltage then the current flowing into small so that the energy loss due to the current and the resistance of the carrier becomes small. In a good transmission and distribution system the quality of insulation is absolutely necessary to ensure the reliability and quality of electric power supply.

Transformer plays an important role in the work process in the industrial world. Transformers should be given special attention, both in monitoring and maintenance. The performance of the transformer is influenced by many factors, both from the transformer itself and from external factors. With the choice of solid and liquid solid isolation will reduce the risk of Partial Discharge. Partial Discharge is a partial discharge on the transformer, ie damage to certain parts of the transformer. PD is not only caused by the transformer itself, but also surrounded by the outside of the transformer or the environment. Short-term caused by PD not directly visible on the operation, but the PD will be fatal if left constantly. Problem formulation From the background then the authors formulate, whether Partial discharge and how to overcome it (1-5).

Partial Discharge on the transformer has a wide scope. For that researchers will limit the problem, namely:
1. Not to discuss the effect of the gas dissolved transformer gases but only to measure the amount of gas that occurs and compare with IEEE Std C57.104 TM -2008 standard.

2. The measurement under study is the occurrence of Partial Discharge on, transformer, especially transformer in PT. Indah Kiat Pulp and Paper, Perawang.

Partial discharge (PD) is the event of electrical spark loss locally in an isolation section in both the inner and surface cavities due to potential differences in the isolation. This phenomenon arise caused by many factors such as quality of dielectric material, gap / cavity in dielectric material, or any damage or imperfection in work post (6).

The load imbalance in a system of electric power distribution is always the case and the cause of the imbalance is the one-phase loads on low voltage network subscribers. Due to the imbalance of the load, the current flows through the neutral of the transformer. The current flowing in the neutral of the transformer causes losses, ie losses due to neutral currents in neutral carriers and losses due to neutral currents flowing to the ground (7-8).

The cause of the occurrence of partial discharge can be done by conducting tests and measurements on the isolation by using the detector of the occurrence of partial discharge. PD tests and measurements relate to quality and quantity values. Quality values can be obtained from the characteristics when testing on certain materials. 
While the value of quantity is the nominal value of the $\mathrm{PD}$ that has dimensions pico Coloumb (pC). Both of these values must meet the standard on the test, so the quality of the new equipment can be assessed (9).

Based on the magnitude of Partial discharges, there are several forms of failure that can occur, namely: 1. 10-15 pC has not happened insulation isolation 2. $<300-500 \mathrm{pC}$ early deterioration of quality of insulation

3. $1000-3000 \mathrm{pC}$ the development of failure, on paper isolation has been a complete failure.

4. $10.000-100.000 \mathrm{pC}$ damage oil insulation resistance occurs. (10)

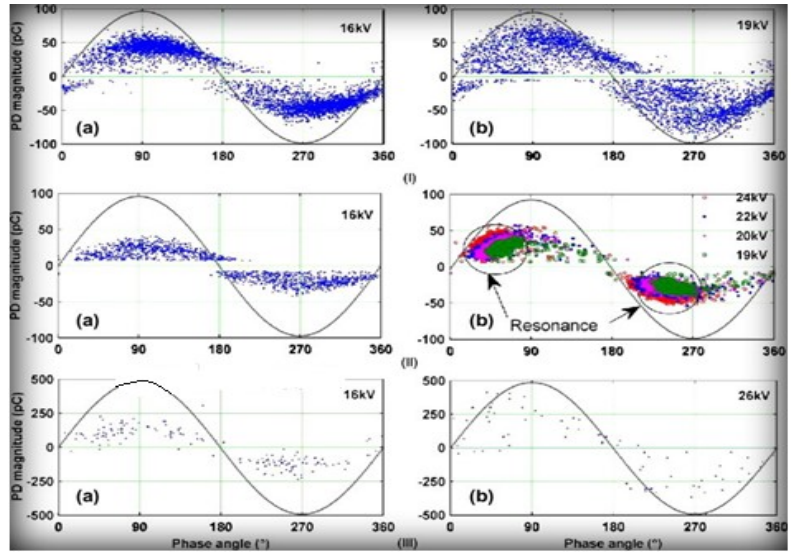

Fig. 1. Partial discharge Grafic

Internal discharge is a Partial discharge that occurs due to a cavity, usually containing air, in isolation. The presence of a cavity inside the insulation makes the dissemination of the electric field in uneven insulation. The electric field in and around the cavity becomes larger than the average electric field in the isolation as shown in fig 2 (11).

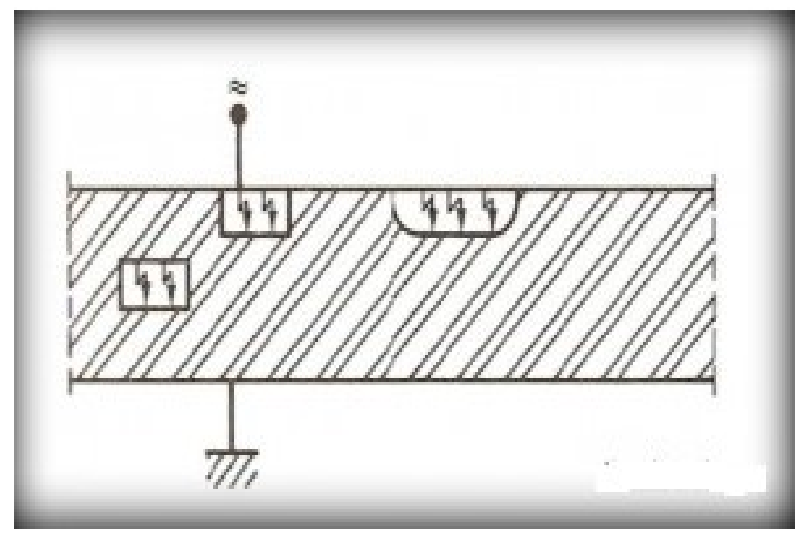

Fig. 2. Internal Partial discharge

Surface discharge is a Partial discharge that occurs on the outside of the insulation or the surface of the insulation. Surface discharge occurs in components where the external discharge touches the surface of the insulation (12).

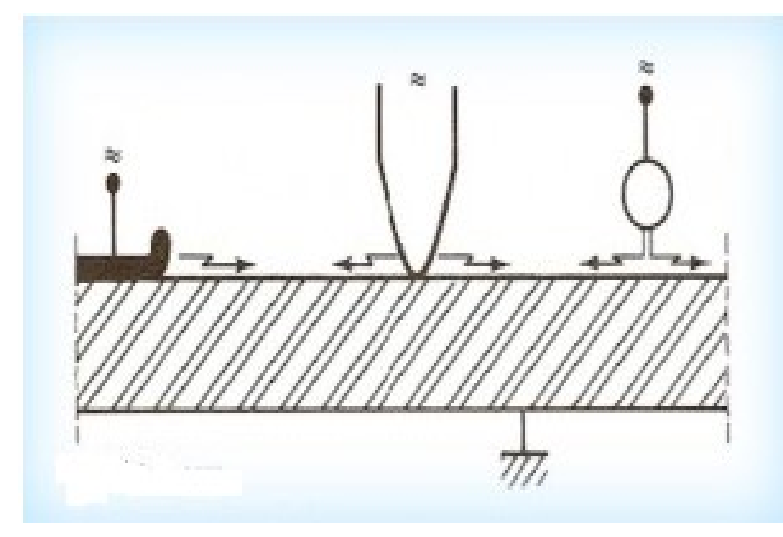

Fig. 3. Surface Partial discharge

In the fig 3 shows some source of surface discharge. At the right and center of the image, the surface discharge occurs due to the presence of an electric field strong enough to cause discharge on the surface of the insulation. The insulating material is a tool used to separate the parts that are on hold or the active parts. The insulating material is an apparatus used as a barrier and safety on electrical equipment having sufficient electric power to ensure the safety system required when the electrical equipment is operating or not operating. The insulating materials used in high voltage engineering are differentiated into: solid insulating materials, liquid insulation materials and gas insulation materials (13)

Failure of isolation is related to Partial Discharge. Partial discharge is the event of loose electrical sparks locally on an isolation section of both the inner and surface cavities due to the potential difference in the isolation. Electromechanical failure is a failure caused by the difference in polarity between the electrodes flanking the solid insulating material resulting in electrical pressure on the material. Electrical pressure that occurs cause mechanical pressure that causes the pull of attraction between the two electrodes. At a voltage of 106 volts / $\mathrm{cm}$ causes mechanical pressure 2 to $6 \mathrm{~kg} /$ $\mathrm{cm} 2$. This mechanical pull or pull This mechanical pull or pull is a force acting on solids associated with Young Modulus (14):

$$
\begin{gathered}
Y=\frac{F / A}{\Delta L / L} \\
\varepsilon_{0} \varepsilon_{\gamma}=\frac{V^{2}}{2 d^{2}}=y \operatorname{Ln} \frac{d_{0}}{d} \\
R=\frac{\left(S_{\gamma}-S_{0}\right) x V \times 10^{-6}}{\mathrm{~T}}
\end{gathered}
$$

Determining the amount of gas dissolved in transformer oil This method is used for comparison between gas space analysis results with the result of gas analysis dissolved in oil. Determine the space of gas and gas dissolved in oil. It should be noted that the equivalent 
value calculated from the TCG, and the experiments measured by probability are often different. This condition is rare, but this equation is needed for the determination of TCG concentration limiting values (15).

$$
T D C G_{\theta}=\sum_{C_{1}}^{C_{n}}\left[\begin{array}{c}
\frac{F_{c}}{B_{c}} \\
--G_{G_{n}} \\
\sum_{G_{g}}^{G_{g}}
\end{array}\right] x 100
$$

Observation of insulation damage in use by the amount of dissolved gas. This method is very appropriate to be used to monitor the condition of damage to transformer insulation material with the calculation of the number of changes in the amount of gas. The amount of gas change is changed, because of the age of the oil itself caused by PD. Because the damage is easily seen when the amount of gas is plotted against time. It can be shown by the equation:

$$
\mathrm{TDCG}_{V}=\frac{F G(V)}{1000000}
$$

Transformer is an electrical equipment that serves to raise and lower the voltage. Step-up transformer serves to raise the voltage, while the step-down transformer serves to lower the voltage. In principle, the transformer consists of two coils (winding), namely primary coil and secondary coil. When the primary coil flows through the current will cause magnetic flux (magnetic field) around it. The strength of the magnetic field is influenced by the magnitude of the flow of electrical current. After the primary coil is flowed by the current and there is GGL (electromotive force) the secondary coil gets the current from the primary coil (15).

In the heating transformer may arise due to energy losses in winding and iron core. The heating process in this transformer will take place continuously during its operation and will cause a rise in temperature on winding and iron core. If this heating process is not balanced with the cooling process, there will be overheating which may result in damage to the transformer. The presence of oil as a filler liquid in the transformer can help the cooling process of winding and core. One of the advantages of oil that can fill the gap or space that will be isolated and simultaneously through the process of energy conversion can channel as well as reduce heat arising from energy loss (16-17)

\section{Research Methods}

This research is very useful to extend the life of the transformer and reduce the number of work accidents. Monitoring of transformer performance with 2 methods, first using Dissolved Gas Analysis (DGA) method and second using Power Partial Discharge (Power PD) Acoustic method. In this study the author took 3 samples of transformers. Using this method, the type information and the amount of gas contained in the transformer oil will be clearly visible. Steps of sampling the transformer oil using DGA method are as follows: 1. Stage of preparation 1. Prepare a bucket to accommodate transformer oil. 2. Install the oil flushing unit on the drain valve main tank transformer. 2. Implementation stage 1. Open drain valve main tank transformer. 2. Perform the process of cleaning / flusing first (remove the oil from the main tank transformer by opening the faucet stop). 3. Close the faucet stop. 4. Place the needle on the syringe. 5. Open the valve on the syringe and inject the syringe on the silicon hose. 6 . Suck oil from the hose. 7. Make sure there is no air (air bubbles) that enter into the syringe. 8. Close the valve back on the syringe. 9. Transfer the oil from the syringe to the bottle / vial by injecting the oil into the bottle / vial without removing the lid. 10 . Take $\pm 50 \mathrm{ml}$ of oil sample for DGA test 11. Wait for the test results from the DGA tool. Performance of measurements with the Acoustic Emission Method, various tools are needed to assist the measurement and analysis of the results obtained as follows: 1. Device PD-TP-500A PD TP-500A is a portable diagnostic system, which periodically monitors Partial Discharges on equipment such as Transformers. PD TP-500A will detect, analyze, and locate the signal source. 2.Sensor In TP-500A PD device there are 2 sensors to check that is: 1. AE (Acoustic Emission) Sensor Is an elastic wave in the material, which is caused by the rapid release of local voltage energy. The source of the event is the phenomenon releasing the elastic energy into the material, which then propagates as an elastic wave. Acoustic emissions can be detected in the frequency range up to $100 \mathrm{MHz}$, but most of the released energy is in the range of $1 \mathrm{kHz}$ to $1 \mathrm{MHz}$. A rapid stress release event produces a stress spectrum that starts at 0 $\mathrm{Hz}$, and typically falls off several MHz. 2. HFCT Sensor (High Frequency Current Transformer) Wideband sensor range, High Frequency Current Transformer (HFCT) HVPD is used to measure partial discharge on the power cord and on the connected HV cable remotely. 3. Cables and Connectors 4. PC / Laptop to display results from checking. 5. Software support to analyze data from measurement or checking results, here I use PowerPD TP500A software. Steps in testing: 1. Attach the AE sensor to the transformer tank wall. 2. Install the HFCT sensor on the grounding. 3. At the time of measurement the result will be displayed on the laptop, the results will display the wave patterns (expected testers are required to have experience to recognize the wave pattern captured by the sensor).

\section{Results and Discussion}

From all analyzes that have been done, the comparison of 3 pieces of the transformer as shown in fig: 4 . The graph shows the dissolved gas content in the three transformers being tested. MCC CLO2 transformer occurs Partial Discharge, where the Hydrogen content has reached 24329 and the calculation of TDCG reached $25975 \mathrm{ppm}$. In the EN-2M transformer, Partial Discharge occurs, where the Hydrogen content has reached 4150 and the calculation of TDCG reaches 5920 ppm. No VE-12 transformer occurs, Partial Discharge, 
where Ethanenya 41.9 content and TDCG calculation results only $630 \mathrm{ppm}$.

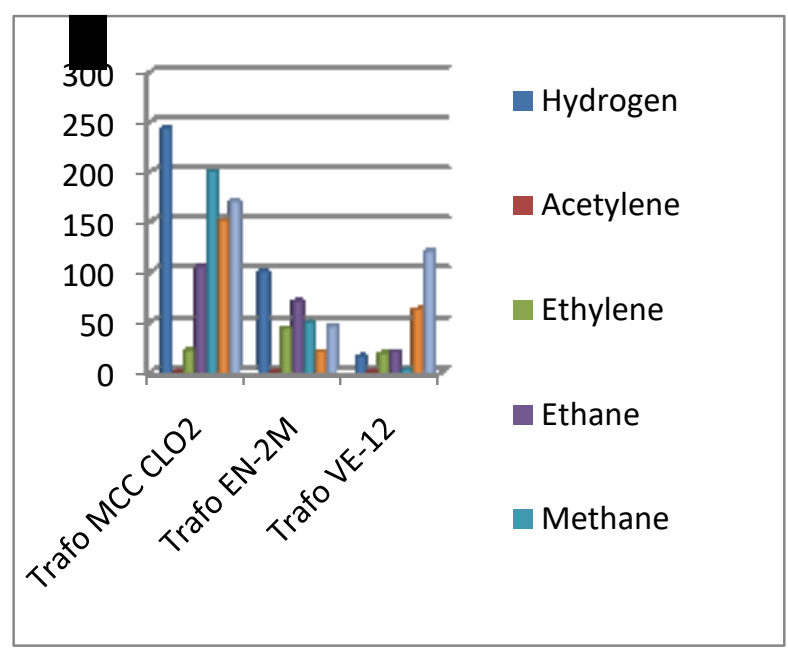

Fig.4. Partial discharge value on the transformer being tested

\section{References}

1. Antonov Bachtiar, Doni Aprinaldo (2015), Optimalisasi Penyeimbang Beban Pada Trafo Distribusi Terhadap Susut Energi (Aplikasi Feeder Sikakap).

2. Antonov Bachtiar, Bayu Dirgantara (2017), Optimalisasi Penyeimbangan Beban Transformator Dengan Metode Seimbang Beban Seharian (SBS) Pada Gardu Depan Kantor Rayon PT. PLN (persero) Rayon Kayu Aro.

3. Nasrul Harun (2016), Rekondisi Transformator Untuk Mengatasi Menurunnya Kemampuan Isolasi Pada Trasformator Daya $20 \mathrm{Kv}$.

4. Aria (2015), IEEE-Std.-C57.104-2008-IEEE-Guidefor-the-Interpretation-of-Gases Generated-in-OilImmersed-Transformers, http://www.ns-aria.com.

5. Djukarna (2013), Transformator, https:// www.djukarna.wordpress.com.

6. Tobing, Bonggas L (2012), Dasar-Dasar Teknik Pengujian Tegangan Tinggi, Erlangga, Jakarta.

7. Abduh, Syamsir (2001), Teknik Tegangan Tinggi, Dasar Pembangkit dan Pengukuan, Salemba Teknika, Jakarta.

8. Bastian (2009), Tugas Akhir, Transformator. 3.2, Institut Teknologi Bandung. Bandung

9. Demmassabu, A.R, Petras, L.S dan Lisi,F (2014), Analisa Kegagalan Transformator Daya Berdasarkan Hasil Uji DGA dengan Motode TDCG, Key Gas, Roger'S Ratio, Duval'S Triangle Pada Gardu Induk, Junal Teknik Elektro, ISSN, 23018402, Manado.

10. Nafiar rizky (2015), Prinsip kerja transformator, https://www. insinyoer. com/prinsip-kerjatransformator/.
11. Pramananda (2011), Analisa Partial Discharge Pada Minyak Isolasi Dengan Menggunakan Metode Deteksi Sinyal Akustik, Jurnal Ilmiah, Jakata.

12. Adrian firman (2009), Isolation transformer, https://www. elektronicaution. wordpress.com.

13. Arora, Rohit Kumar (2013), Different DGA Techniques for Monitoring of Transformers, International Journal of Electronics and Electrical Engineering, Mumbai.

14. Laniya, H and Prof, K.K, Dudani (2015), Partial Discharge Detection and Localization in High Voltage Transformers Using an Acoustic Emission Technique, International Journal, ISSN(O) : 23484470, ISSN(P) : 2348-6406, India.

15. Soebagio (2012), Transformator, ITS Press, Surabaya.

16. Yulistya Negara (2013), Teknik Tegangan Tinggi, Prinsip dan Aplikasi Praktis, Graha Ilmu, Yogyakarta. PT. PLN (Persero) : Buku Pedoman Pemeliharaan Transformator Tenaga, Jakarta.

17. Tadjuddin (1998), Partial Discharge dan Kegagalan Bahan Isolasi, (online), http://www.elektro indonesia.com /elektro /ener13a.html, 2016. 